\title{
WYKONYWANIE ROLI ZAWODOWEJ: PRAWNIK LIMINALNY
}

\section{WPROWADZENIE}

Jak odnotowuje Erving Goffman: „Zgodnie z podstawowym założeniem analizy roli każda jednostka będzie włączona w więcej niż jeden system czy schemat, a więc będzie wykonywać więcej niż jedną rolę. Każda jednostka będzie zatem posiadać kilka osobowości (selves), co każe nam zastanowić się, w jaki sposób te osobowości są ze sobą związane". W ujęciu Goffmana tożsamość człowieka kształtuje się w procesie rozmaitych interakcji, zachodzacych w praktykach społecznych ${ }^{1}$. Tworzą one identyfikacje, tego, kim jesteśmy czy też stajemy się2. W związku ze zbiorem ról, jakie wykonujemy, pojawia się jednak pytanie: czy obejmowanie roli może współistnieć z byciem $\mathrm{w}$ innych profesjach, czy też konieczny jest ścisły podział? Tak jak totalna „segregacja ról” ${ }^{3}$ wydaje się problematyczna, tak też pełna identyfikacja osoby z rola może być źródłem konfliktów i niebezpieczeństw. Na jednym biegunie mamy zatem do czynienia $\mathrm{z}$ brakiem utożsamiania się z rolą, a na drugim $-\mathrm{z}$ całkowitym zaangażowaniem ${ }^{4}$. Poddając krytyce obie wizje wykonywania roli na przykładzie zawodu jurysty, chciałbym zaproponować inna, podkreślając liminalny charakter profesji prawniczej ${ }^{5}$. Ujęciem tym posługuję się na oznaczenie wizji, w której tożsamość osoby w roli jest kształtowana na doświadczeniach różnych praktyk społecznych, w których się uczestniczy. Przewodnia myśla tej propozycji jest idea umiejętności wykonywania różnych ról społecznych, bez nadmiernego uszczerbku dla funkcji, jakie wiążą się z tymi profesjami, a także kondycji osoby, która je realizuje ${ }^{6}$.

* Za uwagi do tekstu dziękuję dr. Pawłowi Jabłońskiemu i mgr. Wojciechowi Zomerskiemu.

${ }^{1}$ Goffman (2010): 72. Podobnie Strauss (2013): 13.

${ }^{2}$ Zob. R.H. Turner (1990): 87.

${ }^{3}$ Określenia tego używa Goffman (2006: 109; 2010: 72).

${ }^{4}$ Mayntz (1970): 373-374.

5 Jeśli z kontekstu rozważań nie wynika inaczej, to pisząc o roli prawnika, mam na uwadze przede wszystkim zawód profesjonalnego pełnomocnika procesowego, tj. adwokata i radcy prawnego. Ponadto pojęciami prawnika i jurysty posługuję się zamiennie. Zob. Kaczmarek (2019): 70-71.

${ }^{6}$ Podnosząc aspekt wykonywania, podkreśla się odejście od statycznego pojmowania roli jako zbioru wzorców postępowań. Zob. Goffman (2010): 119. 
W niniejszym artykule stawiam sobie za cel: po pierwsze, ugruntowanie obrazu „prawnika liminalnego” - w tym celu sięgam do ustaleń z obszaru antropologii kulturowej; po drugie, przedstawienie linii argumentacyjnej odwołującej się do właściwości roli zawodowej, która skłonić ma do rozważenia przedłożonej propozycji. W celu realizacji obu wymienionych zadań przedmiotem badań uczynię kategorię liminalności. Jest ona konstruktem teoretycznym z obszaru antropologii, socjologii organizacji, który przybliża fazy w życiu człowieka, np. okres przejściowy, w którym nastolatek staje się dorosły ${ }^{7}$. Nie jest on wyraźnie dzieckiem ani dorosłym i dlatego może korzystać z obu pozycji. Liminalność opisuje proces przechodzenia z jednej roli w druga albo zajmowania granicznej pozycji w grupie społecznej. W związku z tym kluczowe staje się opracowanie sposobu rozdzielenia lub zintegrowania pojawiajacych się sprzecznych wymagań. To, jak sytuacja ta wpływa na tożsamość osoby, a także samą praktykę instytucjonalna, jest pytaniem stawianym przez badaczy zajmujących się liminalnością.

Jednym z nich jest Victor Turner, który podkreśla, że stan wskazanego zawieszenia konstytuuje tożsamość osoby. Myśl ta aplikowana jest na obszar poszczególnych praktyk społecznych, w tym dyskursu prawniczego $^{9}$. Dokumentując to, zwróćmy uwagę na teoretyczną mape jurystów, jaka rozrysowuje Duncan Kennedy. Autor, realizujac to zadanie, stoi na stanowisku, że można wyróżnić obraz sędziego, który fundowany jest na ujęciu liminalnym ${ }^{10}$. Zgodnie z nim doświadczenie prawnika zawieszone jest między różnymi praktykami instytucjonalnymi, zwłaszcza jurydyczną i polityczna. Podstaw tego zawieszenia, zdaniem Kennedy'ego, można upatrywać w konflikcie wykonywanych ról ${ }^{11}$. Autor przedstawia ten konflikt między innymi na przykładzie wyboru osób na stanowiska sędziowskie czy trybunalskie. Wybór ten można przedstawić za pomocą poszczególnych faz, w których kluczowa staje się ta, w której kandydat obiecuje po objęciu urzędu orzekać, podejmować decyzje na podstawie prawa, a nie bliskich mu poglądów społeczno-politycznych. To prawo odseparowane od ideologii ma stać się punktem odniesienia w pracy orzeczniczej sędziego ${ }^{12}$. Realność tego przejścia podaje w wątpliwość Kennedy, przedstawiając obraz prawnika liminalnego, który w działalności zawodowej uwzględnia oba subświaty instytucjonalne. Do wizji liminalnego jurysty w ujęciu zaproponowanym przez Duncana Kennedy'ego odwołuje się Rafał Mańko. Autor ten eksponuje obraz sędziego jako zawieszonego w działalności orzeczniczej między praktyka jurydyczną i polityczna ${ }^{13}$. Przybliżając to ujęcie, Mańko pisze: ,juryści limi-

${ }^{7}$ Turner (2006): 119.

8 Turner (2006): 111.

${ }^{9}$ Poza przedmiotem analiz pozostawiam problem wykluczenia społecznego, studiów nad uchodźcami, który podejmowany jest również z wykorzystaniem fazy liminalnej, zob. Łodziński, Ząbek (2010): $103 \mathrm{n}$.

${ }^{10}$ Kennedy (2014): $114 \mathrm{n}$.

${ }^{11}$ Kennedy (2014): 125.

${ }^{12}$ Kennedy (2014): 114.

${ }^{13}$ Mańko (2018): 203. 
nalni położeni są na granicy między subświatem politycznym a subświatem prawnym, a właściwie są swego rodzaju "wtyczką" świata politycznego wetkniętą w świat prawny. Są więc podmiotami z zewnątrz, które przybywaja do subświata prawnego ze z góry określonym programem ideologiczno-politycznym"14.

Zaprezentowany wyżej zamiar adaptacji kategorii liminalności do opisu roli i pozycji prawnika wpisuje się zatem w obecną już w jurysprudencji ścieżke aplikacyjna. Tak postawiony cel zostanie zrealizowany w trzech etapach. Punktem wyjścia czynię rozpoznanie pojęcia liminalności. W tym zakresie odwołam się do ustaleń dwóch antropologów Arnolda van Gennepa i Victora Turnera (II). W kolejnym kroku omówię za Jonasem Söderlundem i Elisabeth Borg dominujące sposoby badania liminalności w literaturze z zakresu socjologii organizacji i zarządzania grupami zawodowymi (III). W ostatnim punkcie ustalenia te odniosę do tezy o rozdziale ról, a następnie na jej podstawie postaram się wykazać, że dostarcza ona argumentacji na rzecz myślenia o prawniku w kategoriach liminalności (IV).

\section{POJĘCIE LIMINALNOŚCI}

Pojęcie liminalności zostało wprowadzone przez van Gennepa na oznaczenie zmiany „miejsca, stanu, pozycji społecznej i wieku”15. Antropolog przedstawia rytuał przejścia w świetle trzech faz: separacji (wyłączenia), przejścia (liminalności) i integracji (włączenia) ${ }^{16}$.

Pierwszy etap - separacja - polega na symbolicznym albo fizycznym oderwaniu się osoby od grupy społecznej, do której dotychczas należała. Proces ten znamionuje zerwanie z tożsamościa, która stanowiła podstawowy punkt odniesienia w identyfikacji człowieka. Drugi etap - liminalny - oznacza (po łacinie) próg. Wskazana graniczność sugeruje, że faza ta znajduje się pomiędzy tożsamością grupy społecznej wyłączającej a włączającej i charakteryzuje ją balansowanie między nimi. Stąd też określenie liminal persona - „człowiek progu”. W fazie tej jednostka kształtuje swoją tożsamość przez doświadczanie różnorakich praktyk. Trzecią fazę - integracyjną - charakteryzuje przyjęcie identyfikacji wyznaczanej przez nową strukturę instytucjonalną. Uznaniu temu może towarzyszyć wyłączenie innych doświadczeń i osądów.

Rozróżnienie wymienionych faz zostało przyjęte przez Turnera. Badacz ten posługuje się wskazana trajektorią zmiany najpierw w badaniach dotyczących społeczności plemiennej, a następnie do opisu wykonywania ról społecznych ${ }^{17}$. W obu aspektach omawiane fazy wykazuja, że życie społeczne jest procesem, w którym można wyróżnić „następujące po sobie bytowe doświad-

\footnotetext{
14 Mańko (2018): 204.

15 Przywołuję za Turnerem (2010: 115). Zob. także van Gennep (2006): 30.

16 Van Gennep (2006): 36; Turner (2005a): 196.

17 Turner (2005b): 83 n.; (2010): 125. Zob. także Jaskulska (2013): 82 n.
} 


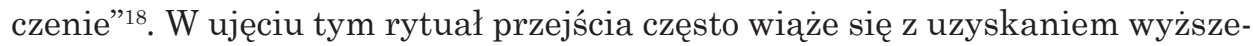
go statusu społecznego, pozycji w strukturze instytucjonalnej ${ }^{19}$. Ze względu na obietnicę jej osiągnięcia, praktyka instytucjonalna staje się podstawową grupa odniesienia, mająca wpływ na to, kim się osoba staje.

Turner, przedstawiając fazę liminalną w opozycji do dwóch pozostałych etapów, zwłaszcza integracyjnego, posługuje się opozycją communitas (wspólnota) a struktura społeczna ${ }^{20}$. Fazę liminalną odnosi on do pojęcia wspólnoty, a integracyjna - do pojęcia struktury. Przyporządkowanie to przedstawiane jest z punktu widzenia pozycji człowieka w strukturze społecznej. Etap integracyjny charakteryzuje: a) uznanie roli struktury organizacyjnej za określająca sposób działania jednostki oraz b) moralność tzw. zamknięta, która nie pozostawia miejsca dla sytuacji wyboru. W ujęciu tym, jak odnotowuje Turner: „jednostkami są tu statusy i role, a nie konkretne jednostki ludzkie”21.

$\mathrm{Z}$ odmiennym obrazem człowieka mamy do czynienia $\mathrm{w}$ fazie liminalnej. Przedstawiając ja, Turner posługuje się pojęciem wspólnoty w celu podkreślenia, po pierwsze, słabszego aniżeli w przypadku struktury znaczenia hierarchicznego podziału organizacji pracy; po drugie, już wspominanego wyżej kształtowania tożsamości jednostki w świetle różnych doświadczeń. Charakteryzując tę właściwość, interesujący nas antropolog używa określenia moralność otwarta. Zakłada ona, że moralność instytucjonalna nie reguluje działania jednostki w sposób całościowy, pozostawiając miejsce do oceny, indywidualnego osądu zdarzenia czy też sytuacji ${ }^{22}$. W ten sposób kształtuje się samoświadomość człowieka, który wykonując czynności, pozbawiony jest czynnika strukturalnego w pełni odciążającego od sytuacji wyboru ${ }^{23}$. Powoduje to przedstawianie pojęcia roli z uwzględnieniem zmiennej w postaci osoby, która ją wykonuje. Dzięki temu zyskuje ona podmiotowość i realne poczucie odpowiedzialności za podejmowane działanie ${ }^{24}$.

Tożsamość jednostki w fazie liminalnej kształtuje się na różnych identyfikacjach $^{25}$. Wspomniany już brytyjski antropolog Turner zwraca na to uwagę, podkreślając, że osoby „sa jednocześnie członkami dwóch lub więcej grup społecznych, których społeczne zdefiniowanie i normy kulturowe są różne, a często nawet sprzeczne"26. Victor Turner, przybliżając tę sytuację, odwołuje się do pojęcia zbioru ról Roberta Mertona. W tym ujęciu liminalność polega na umiejętności takiego wykonywania ról, które nie zakłada uznania tożsamości jednej z pełnionych profesji za punktu odniesienia pozostałych sfer życia społecznego. Oznacza to, z jednej strony, że żadna z wykonywanych profesji nie

\footnotetext{
18 Turner (2010): 117.

19 Turner (2005a): 196.

20 Turner (2010): 117.

21 Turner (2005a): 200.

22 Turner (2010): 127.

23 Turner (2005a): 215.

${ }^{24}$ V. Turner (2006: 120) pisze: „Ludzie mogą »być sobą", jak to się mówi, kiedy nie odgrywają zinstytucjonalizowanych ról. Role niosą także z sobą odpowiedzialność [...]”.

25 Turner (2005a): 196-197.

26 Turner (2005a): 196-197.
} 
determinuje w pełni tego, kim się jest. Z drugiej natomiast - wskazane bycie w zbiorze ról i związane $\mathrm{z}$ nim doświadczenie ma wpływ na tożsamość człowieka. Składa się na nią wielość identyfikacji jednostki, a w sytuacji wykonywania konkretnej roli jedna z nich zyskuje funkcję podstawowego punktu odniesienia. Liminalność ilustruje zatem nie tylko wielość praktyk społecznych, w których uczestniczy osoba, ale i umiejętność przechodzenia między nimi. W ujęciu tym liminalność jest już kategoria, która zawiera w sobie komponent dyrektywalny. Z tego też chyba powodu, jak odnotowuje Turner, pedagogika liminalności poddaje krytyce dwa sposoby działania w roli²7. Pierwszy, który polega na kierowaniu się wyłącznie regułami struktury społecznej. Z kolei drugi, podawany w wątpliwość obraz polega na kierowaniu się w działalności rolowej moralnością indywidualną. Na tej podstawie można przyjać, że rekomendowany model działania zakłada umiejętność uwzględniania różnych czynników, których doświadczamy, wykonując role społeczne.

Badania van Gennepa i Turnera łączy, po pierwsze, przedstawianie liminalności jako fazy rytuału. Dla obu autorów liminalność (przynajmniej w punkcie wyjścia) jest etapem przejściowym, przez który przechodzi osoba czy też grupa społeczna w celu nabycia nowej tożsamości. Zawieszenie między pozycjami czy też etapami społecznymi jest tymczasowe, czasowo ograniczone ${ }^{28}$. W ten sposób podkreśla się, że osoba nie jest już zakorzeniona w danej praktyce; jest właśnie na marginesie stabilnych struktur społecznych, które w pełni odciążaja jednostkę od sytuacji wyboru. Po drugie, w ustaleniach obu antropologów z faza liminalną łączy się często atrybut magiczno-religijny ${ }^{29}$. Na poziomie symbolicznym może mieć to swoje przełożenie na strój, język czy też architekturę miejsca, np. sali sądowej. Z kolei w sferze ideologicznej atrybut religijny łączy się z wiara w zbiór reguł, którymi mają się posługiwać osoby w fazie liminalnej.

\section{LIMINALNOŚĆ JAKO PROCES, POZYCJA I PRZESTRZEŃ}

Nieco odmienne spojrzenie na liminalność zaprezentowały ostatnio Maryann McCabe i Elizabeth K. Briody. Ich zdaniem należy ją traktować nie jako sytuację przejściowa, ale stan, który wymusza poruszanie się między różnymi praktykami społecznymi ${ }^{30}$. W ujęciu tym liminalność nie tyle opisuje transformacyjna zmianę, ile charakteryzuje zajmowaną pozycję, która ma charakter złożony tożsamościowo w dłuższym okresie.

Zasygnalizowana odmienność w pojmowaniu liminalności została udokumentowana w badaniach Söderlunda i Borg ${ }^{31}$. Celem podjętych przez nich analiz było przedstawienie dominujacych ujęć liminalności w opracowaniach

\footnotetext{
27 Turner (2010): 123.

${ }^{28}$ Newcomb, Turner, Converse (1970): 428.

29 Turner (2010): $124 \mathrm{n}$.

30 McCabe, Briody (2016): 2. Zob. także Ibarra, Obodaru (2016).

31 Söderlund, Borg (2018): 881-882.
} 
z obszaru socjologii organizacji i zarządzania ${ }^{32}$. Söderlund i Borg, realizując tak postawione zadanie, wyróżnili trzy podstawowe sposoby rozpatrywania liminalności jako odpowiednio: a) procesu, b) pozycji i c) przestrzeni (miejsca) ${ }^{33}$.

W badaniu liminalności jako procesu widoczne jest odchodzenie od pojmowania jej jako fazy przejściowej na rzecz sytuacji, która modeluje tożsamość osoby $^{34}$. W analizach tych dominują pytania o tożsamość człowieka w roli czy też tożsamość zawodową. Z jednej strony podkreśla się, że ujęcie liminalne charakteryzuje odejście od kształtowania tożsamości osobowej opierającej się na jednym doświadczeniu na rzecz uznania wielości identyfikacji. Zmiana ta jest konsekwencją definiowania siebie, opierającego się na różnych praktykach społecznych czy instytucjonalnych. Z drugiej zaś strony pytanie o tożsamość zawodową podejmowane jest z punktu widzenia rozwiązań instytucjonalnych, koncentrujących się na tym, w jaki sposób instytucja może modelować obraz wykonawcy roli. Procesualny charakter liminalności zakłada, że sekwencja kroków prowadzących do roli docelowej nie jest w pełni określona. Jej zmienność jest ważna ze względu na umiejętność reagowania na zmiany społeczno-instytucjonalne, np. w zakresie nowych technologii. Nieokreśloność ta powoduje, że osoba w roli jest przygotowywana do rozwiązywania problemów, również tych, które nie mieszczą się w instytucjonalnym skrypcie.

W przedstawieniu liminalności jako procesu kluczowa jest ekspozycja ról, jakie wykonujemy w przestrzeni publicznej i ich wpływ na tożsamość osoby. Aspekt wielowymiarowości powraca w ujęciu liminalności jako pozycji. Z ta jednak różnica, że wskazana złożoność dotyczy wykonywanej roli ${ }^{35}$. Jej źródłem są odmienne oczekiwania albo zadania, jakie formułuje się w ramach profesji. Przykładem liminalności jako pozycji są role, których realizowanie zakłada interakcje z różnymi grupami adresatów, np. klientem a członkami grupy zawodowej. Interakcje te mogą odsłaniać odmienne wartości, które można przyporządkować odpowiednio do racji społecznych, instytucjonalnych czy też zindywidualizowanego klienta ${ }^{36}$.

Wykonywanie liminalnej pozycji skłaniać może do postawienia pytania, w jaki sposób można rozdzielić albo zintegrować sprzeczne oczekiwania. Jedna z udzielanych odpowiedzi zwraca się w stronę tożsamości zawodowej, która oferuje różne obrazy wykonywania roli. Liminalność oznacza w tym przypadku nabycie kompetencji, która zakłada umiejętność przechodzenia między różnymi wizjami wykonywania roli ${ }^{37}$. Liminalność zakłada zatem, że osoba w roli nie identyfikuje się $\mathrm{z}$ jednym konkretnym obrazem, nie można jej do niego zakwalifikować.

Z ustaleń na temat liminalności jako pozycji można wyprowadzić wniosek, że rola zawodowa oferuje różne „twarze” wykonywania profesji. W związku

${ }^{32} \mathrm{~W}$ tym celu przedmiotem badań uczyniono artykuły naukowe, indeksowane w Web of Science, Scopus.

33 Söderlund, Borg (2018): 884 n.

34 Söderlund, Borg (2018): 885-886.

35 Söderlund, Borg (2018): 887.

36 Söderlund, Borg (2018): 889-900.

37 Borg, Söderlund (2015): 260 n. 
z tym zajmowanie liminalnej pozycji zakłada pewną swobodę w przemieszczaniu się w zakreślonych przez strukturę instytucjonalną granicach. Można powiedzieć, że rola dostarcza skryptu, w którym można wyróżnić odmienne identyfikacje wykonywania profesji. Przyjmowanie ich jest zadaniem osoby, która ją wykonuje.

Z kolei w przedstawieniu liminalności jako przestrzeni szczególnym przedmiotem zainteresowania są miejsca graniczne: a) między różnymi praktykami społecznymi albo b) jednej praktyki, w obrębie której mamy wydzielone strefy wymagajace przechodzenia między nimi ${ }^{38}$. Relacje między przestrzenią a jej uczestnikami ujmuje się dialogicznie. W ujęciu tym architektura przestrzeni ma wpływ na tożsamość osób, a z kolei to, kim są uczestnicy danej praktyki, nie pozostaje bez wpływu na kształt przestrzeni społecznej. Tytułem przykładu zagospodarowanie przestrzeni sądowej może mieć wpływ na faktyczne funkcjonowanie wymiaru sprawiedliwości, a także odbiór prawa w sferze publicznej. W ramach badań nad liminalną przestrzenią pojawia się również pytanie o wpływ życia zawodowego na życie prywatne i związane z tym potencjalne napięcia ${ }^{39}$. Mamy z nimi do czynienia w sytuacji, gdy osoba odczuwa głęboki konflikt między poszczególnymi rolami, jakie wykonuje w przestrzeni publicznej. Odsłania on napięcie między konkurującymi systemami wartości, które mają wpływ na indywidualne samopoczucie, a w konsekwencji zachowanie odrębności wobec struktur instytucjonalnych, zwłaszcza tej, która wysuwa roszczenie do przejęcia funkcji podstawowego punktu odniesienia ${ }^{40}$.

Z badań nad wyróżnionymi ujęciami liminalności (procesu, pozycji i przestrzeni) Söderlund i Borg wyprowadzają jej znaczenia jako doświadczenia i rytualizację $e^{41}$. W pierwszym z nich liminalność wiąże wielość wykonywanych ról z doświadczeniem, które ma wpływ na kształtowanie tożsamości osoby. W tym kontekście pojęcie doświadczenie liminalne używa się na oznaczenie sytuacji, w której tożsamość osoby fundowana jest na identyfikacjach pochodzących z różnych praktyk. Z kolei drugie ujęcie - rytualizacja liminalna koncentruje się na sposobie wykonywania roli. W ujęciu tym rytualizację można rozumieć jako ramy, w których można wyodrębnić różne obrazy.

\section{PRAWNIK LIMINALNY: ARGUMENT Z TEZY O ROZDZIALE RÓL}

Sierk Ybema, Nic Beech i Nick Ellis wysuwają propozycję, która koresponduje z zaprezentowanym znaczeniem liminalności jako doświadczenia i rytualizacji ${ }^{42}$. W jej świetle liminalność można przyporządkować do opisu dwóch różnych sytuacji. Pierwsza z nich związana jest z przypadkiem,

38 Söderlund, Borg (2018): 891-893.

39 Ibarra, Barbulescu (2010): $140 \mathrm{n}$.

40 Ibarra, Barbulescu (2010): 140.

${ }^{41}$ Söderlund, Borg (2018): 893-896. Autorzy wskazują również na dwa inne ujęcia, które pozostawiam w tym artykule poza przedmiotem uwagi.

42 Ybema, Beech, Ellis (2011): 22. 
w którym jednostka odgrywa różne role w przestrzeni publicznej, stanowiące ważne punkty odniesienia tego, kim się jest. Natomiast drugie ujęcie liminalności związane jest z tożsamością roli, która kształtuje różne obrazy jej wykonywania. Oba ujęcia można odnieść do tezy o rozdziale ról. Zakłada ona, że obowiązki związane z zawodem prawnika zmuszają jej wykonawcę do dokonywania wyborów moralnych ${ }^{43}$. Ich źródłem są konflikty między wymaganiami, jakie wiążą się np. z rolą pełnomocnika procesowego, a innymi zobowiązaniami, związanymi z pełnionymi funkcjami w przestrzeni publicznej ${ }^{44}$. Im bardziej wyraźne jest zróżnicowanie pomiędzy tymi wymaganiami, systemami norm, które one ujawniaja, tym trudniej jest jednostce zintegrować ze sobą różne odgrywane przez siebie role. Obok sytuacji konfliktu między profesjami można wskazać na inne jeszcze aspekty konfliktu, dotyczące napięcia między zadaniami w ramach roli. Jak odnotowuje Ija Lazari Pawłowska, tego rodzaju konflikty występują w profesjach, w których mamy do czynienia z wielością partnerów ${ }^{45}$. Tezę o rozdziale ról można zatem rozpatrywać w dwóch ujęciach, nazwijmy je zewnętrznym i wewnętrznym. Pierwsze z nich zwraca uwagę na zbiór ról, jakie wykonujemy w przestrzeni publicznej. Z kolei drugie ujęcie - wewnętrzne - koncentruje się na zbiorze zadań w ramach wykonywanej profesji. Łączy je sytuacja konfliktu między odpowiednio rolami albo zadaniami.

Teza o rozdziale ról w ujęciu zewnętrznym podkreśla fakt uczestniczenia w różnych praktykach społecznych. Zobowiązania, jakie one formułuja, moga tworzyć sytuację konfliktu. Pytanie o sposób jej rozstrzygania jest podejmowane w debacie o modelowaniu tożsamości wykonawcy roli. W jej zakresie można wyróżnić dwa podstawowe ujęcia socjalizacji zawodowej: deterministyczne i interakcyjne. Propozycja deterministyczna oparta jest na następujących założeniach ${ }^{46}$ :

1) relacje między instytucją a jednostką mają charakter jednokierunkowy;

2) instytucje formułuja roszczenie do integralności przez pełne zinternalizowanie moralności instytucjonalnej przez uczestników praktyki;

3) działanie w instytucji kształtowane jest na podstawie imperatywów, które odciążają osobę w roli od sytuacji wyboru;

4) tożsamość osoby w roli jest przedmiotem socjalizacji ${ }^{47}$.

$\mathrm{W}$ modelu deterministycznym przyjmuje się zatem, że człowiek w działalności zawodowej dostosowuje się do zastanych wzorców, oddając się roli, reprodukuje schemat poznawczy ${ }^{48}$. W opozycji do przedstawionej wizji kształtuje się model interakcyjny. Kluczowe dla tego ujęcia jest podkreślanie sprawstwa podmiotowego jako mającego wpływ na uczestniczenie jednostki w praktyce społecznej. Ekspozycja sprawstwa podmiotowego niesie ze soba

\footnotetext{
43 Stier (1991): 554; Wendel (2014): 3-11.

44 Stier (1991): 560; Markovits (2008): 103-104.

${ }^{45}$ Lazari-Pawłowska (1971): 49 n.; Czapska (1989): 53.

${ }^{46}$ Odwołuję się do ustaleń: Borucka-Arctowa, Skapska (1993): 13.

47 Borucka-Arctowa, Skapska (1993): 12.

48 Goffman (2010): 86-87.
} 
określone konsekwencje, pośród których istotne jest osłabienie wymiaru instytucjonalno-prawnego. Stopień tego osłabienia można mierzyć możliwościa rewizji reguł prawnych jako wyznaczających sposób postępowania, podejmowania decyzji.

Oba modele w swych skrajnych formach ujawniaja potencjalne niebezpieczeństwa. Modelowi deterministycznemu stawia się zarzut kształtowania obrazu bezwolnej jednostki, której etyczność działania sprowadza się do postępowania według zastanych reguł. Taki obraz działania w roli można odnieść do opisu banalności zła w ujęciu Hannah Arendt. Z kolei wobec interakcjonizmu wysuwa się zarzut nadmiernego podkreślania roli czynników subiektywnych za cenę niedocenienia infrastruktury prawnej. Podstaw tego zarzutu można upatrywać w tym, że wykonywanie zawodu prawnika czy sędziego oparte jest na zaufaniu, że to rozpoznawalne intersubiektywne czynniki, takie jak np. tekst prawny, są ważnymi determinantami mającymi wpływ na podejmowane decyzje. W wizji tej stanowią one ramę wyznaczającą działanie jurystom ${ }^{49}$.

Problem relacji na linii jednostka a instytucja podejmowany jest również z perspektywy wzajemnych interakcji. Wpływ tożsamości instytucjonalnej na człowieka w roli nie budzi większych wątpliwości. Podważana jednak bywa rola jednostki. H. Ralph Turner, rehabilitując ten aspekt relacji, wskazuje na racje skłaniające do odejścia od jednostronnego postrzegania interakcji ${ }^{50}$. Pierwsza z nich dotyczy zmiennej w postaci pozycji jednostki w strukturze instytucjonalnej. Osoby zajmujące wysokie stanowiska mają wpływ na sposób zarządzania instytucja. Drugi argument wskazuje, że jeśli na skutek działania osób rekomendowana przez nie praktyka staje się strategią postępowania, to możemy mówić o wpływie osoby na rolę. Ponadto, zdaniem R.H. Turnera, w przedstawieniu pozycji jednostki ważne są także zmienne, takie jak płeć, wiek czy pochodzenie społeczne ${ }^{51}$. Ujęcie liminalne rozwija ten trop, podkreślając, że tożsamość wykonawcy roli kształtuje się na różnych doświadczeniach, pochodzących z praktyk społecznych, w których się uczestniczy. W trakcie tego procesu nieunikniona jest sytuacji napięcia między doświadczeniami. Postać tego napięcia, które kształtuje tożsamość osoby, można rozrysować w świetle dwóch pojęć: fragmentaryzacji i narracyjności ${ }^{52}$.

Fragmentaryzacja zakłada możliwość kierowania się standardami w poszczególnych praktykach, w których uczestniczymy, a przy okazji tego selektywne zapominanie o sytuacji konfliktu między nimi. Ralph H. Turner nazwał ten proces mianem szufladkowania ról i zadań ${ }^{53}$. Z jednej strony szufladkowanie to ma na celu łagodzenie obciążenia związanego z koniecznością rozstrzygania ponad miarę sytuacji konfliktu, np. między moralno-

\footnotetext{
49 Jabłoński, Kaczmarek (2017): 15-22.

50 R.H. Turner (1988): 2 n.

51 R.H. Turner (1988): 3.

52 Ybema et al. (2009): 311-314; Ibarra, Barbulescu (2010): 135 n.; Costas, Fleming (2009):

${ }^{53}$ R.H. Turner (2006): 250. Piszę na ten temat także w: Kaczmarek (2020): 47-49.
} $353 \mathrm{n}$. 
ścią instytucjonalna a moralnością indywidualną. Z drugiej strony pozwolić ma ono na wykonywanie różnych ról w sferze życia codziennego. Można być skapym biznesmenem, a jednocześnie hojną osobą w gronie przyjaciół. Podobnie od współpracowników można oczekiwać staranności i skrupulatności, a w życiu rodzinnym być nad wyraz pobłażliwym wobec odmiennych postaw i zachowań.

Szufladkowanie zadań, podejmowanych czynności nie oznacza jednak braku ciagłości w kształtowaniu tożsamości. Aspekt ten eksponuje pojęcie narracyjności. Ilustruje ono, że praktyki, w których uczestniczymy, mają wpływ na to, kim jesteśmy. Zbiór ról tworzy narracyjny wymiar tożsamości, który zmienia się na skutek wykonywanych profesji ${ }^{54}$. Dopełnia on i integruje poszczególne identyfikacje, które odpowiadają wykonywanym rolom czy też zadaniom. Celem aspektu narracyjnego jest zatem tworzenie poczucia ciagłości między tym, kim się było, a tym, kim się staje. Fragmentaryzacja uwyraźnia z kolei sytuacje, w której ludzie mają nie jedna, ale wiele współistniejaccych identyfikacji, które zapewniają elastyczną prezentację siebie.

Przedstawiony proces kształtowania tożsamości wskazuje na potencjalne napięcia między wykonywanymi rolami. Diagnozę tę można odnieść również do roli społecznej, wskazując, że w jej obrębie możemy mieć do czynienia z sytuacją konfliktu między zadaniami czy też oczekiwaniami wobec roli ${ }^{55}$. Zwraca na to uwagę Goffman:

\footnotetext{
Definiując rolę społeczna jako deklarację praw i obowiązków przypisanych danej pozycji społecznej, możemy powiedzieć, że rola społeczna obejmuje jedną lub więcej ról granych przy kolejnych okazjach przez wykonawcę przed publicznością tego samego rodzaju lub przed publicznością złożoną z tych samych osób ${ }^{56}$.
}

W sytuacji gdy tożsamość roli nie oferuje jednego wzorca jej wykonywania, ale różne obrazy, możemy mówić o interesującej nas liminalności ${ }^{57}$. Co więcej, zdaniem Herminia Ibarra i Otilia Obodaru, wizje te moga pozostawać względem siebie w konflikcie ${ }^{58}$. Sytuacja ta stanowi ilustrację tezy o rozdziale ról w aspekcie wewnętrznym. W tym ujęciu pojęciem liminalna rola posługujemy się na oznaczenie sytuacji, w której mamy do czynienia z zawieszeniem między różnymi identyfikacjami w ramach wykonywanej profesji. Zawieszenie takie w zawodzie prawnika, odwołując się do pojęcia liminalności, odnotowuje Orit Kamir ${ }^{59}$. Badaczka ta, przybliżając figurę prawnika bohatera, wskazuje, że jest ona kształtowana na dwojakiego rodzaju zobowiązaniu, odpowiednio wobec społeczeństwa oraz klienta. W ujęciu tym liminalność polega na zachowaniu w praktyce zawodowej próby równowagi między racjami społecznymi i zindywidualizowanego klienta. Taki obraz prawnika Kamir przeciwstawia

\footnotetext{
${ }^{54}$ Costas, Fleming (2009): 365.

55 Ibarra, Barbulescu (2010): 144.

${ }^{56}$ Goffman (2008): 45.

57 Ibarra, Obodaru (2016): 32.

58 Ibarra, Obodaru (2016): 32-33.

59 Kamir (2014): $747 \mathrm{n}$.
} 
wizji, w której osobowość jurysty jest modelowana przez imperatywy instytucjonalne. W ujęciu tym nie jest on już osobą w roli, ale członkiem profesjonalnej grupy. Z tej perspektywy prawnik liminalny jest na marginesie tak rozumianej wspólnoty, ponieważ $\mathrm{w}$ pełni się z nią nie identyfikuje. Jego doświadczenie fundowane jest na zbiorze wykonywanych ról, bywa że konfliktowych względem siebie.

Podobną dualistyczną formę zobowiązania, jaka spoczywa na roli prawnika - nie nawiąujac do kategorii liminalności - przedstawia Robert W. Gordon $^{60}$. Zdaniem tego autora jedno z zobowiązań koncentruje się na reprezentacji klienta i uwzględnieniu jego racji. Z kolei drugie zobowiązanie łączy się ze społeczną funkcją profesji prawniczej. W powinności tej podkreśla się, że kluczowe dla zawodu jurysty jest stanie na straży prawa jako mechanizmu układania relacji między ludźmi. Gordon, przybliżając tak rozumianą funkcję obywatelska, która spoczywa na prawnikach, odwołuje się do słów Hipokratesa: „Po pierwsze, nie szkodzic”" ${ }^{1}$. W jej świetle zadaniem adwokata czy radcy prawnego jest niepodejmowanie czynności, które pomnożone mogłyby osłabić normatywną wydolność prawa.

Przedstawiona postać zobowiąania, jaka spoczywa na profesji prawniczej, może prowadzić do wielości identyfikacji w ramach wykonywanej roli, co ilustrują badania Marvina W. Mindesa i Alana C. Acocka, przeprowadzone na dwóch grupach respondentów: prawnikach, tj. adwokatach i sędziach, oraz społeczeństwie ${ }^{62}$. W świetle odpowiedzi respondentów autorzy tekstu: Trickster, hero, helper: a report on the lawyer image wyprowadzili wniosek, że instytucjonalne oraz społeczne oczekiwania nie układają się w jedną wizję prawnika ${ }^{63}$. Tworzą ja bowiem trzy figury przedstawiajace jurystę jako: bohatera, oszusta i pomocnika. Mimo że figury te omawiane są często jako abstrakcyjne etykiety, to - zdaniem autorów - stają się one opisem oczekiwanego wykonywania roli. Jak bowiem wynika z odpowiedzi udzielonych przez prawników, umiejętność łączenia wskazanych trzech identyfikacji w działalności zawodowej jest zadaniem jurysty. Oczekuje się bowiem od niego, że będzie zarówno przebiegły, jaki i pomocny. Jego bohaterskie czyny mają przeplatać umiejętności bycia cwanym, ale i zarazem uczynnym ${ }^{64}$. „Każdy prawnik jest złożoną mieszanką cech i zachowań, składających się na Bohatera, Oszusta i Pomocnika"65. Wymienione identyfikacje tworza nie tylko tożsamość zawodowa, ale i społeczną wizję prawników w przestrzeni publicznej. Ustalenia te stanowią argument na rzecz pojmowania prawnika w kategoriach liminalności ${ }^{66}$. Ilustruje ona wielość identyfikacji, które składają się na tożsamość człowieka w roli.

60 Gordon (2000): 42.

61 Gordon (2000): 45.

${ }^{62}$ Mindes, Acock (1982). Na badania te powoływałem się również w pracy: Kaczmarek (2019): $62-68$

63 Podobne wnioski, w odniesieniu do funkcji, jakie pełnią sędziowie rodzinni, formułuje Magdalena Arczewska (2009: rozdz. III i IV).

64 Mindes, Acock (1982): 211. Por. Zienkiewicz (2019): 44-47.

65 Mindes, Acock (1982): 229.

66 Zob. Mindes, Acock (1982): 212-213. 


\section{WNIOSKI}

W niniejszym artykule starałem się argumentować na rzecz propozycji prawnika liminalnego. Przypomnijmy, że modelowo można wyróżnić dwa obrazy wykonywania roli ${ }^{67}$. Pierwszy z nich polega na pełnej identyfikacji osoby z profesją. W tym przypadku tożsamość zawodowa staje się punktem odniesienia działalności człowieka nie tylko w praktyce instytucjonalnej, ale i pozostałych sferach aktywności. W tym przypadku cechy roli i osoby, która ja wykonuje, przyjmują niemal znak równości. Drugi z modeli oparty jest z kolei na dystansie do roli, który ma aspekt instrumentalny ${ }^{68}$. W tym obrazie mamy do czynienia z brakiem identyfikacji z pełnionym zadaniem. Rola w tym przypadku jest narzędziem do uzyskania celu, bywa, że sprzecznego z wymogami wykonywanej profesji. Główny zarzut, jaki można postawić wobec tak rozumianego dystansu, dotyczy legitymizacji praktyki, której celem jest ucieczka od odpowiedzialności i bezosobowość działania; zgodnie z formułą: tylko wykonuję rolę, nie odpowiadam za dokonywane czynności.

Można jednak wyróżnić trzeci model. Przedstawiając tę propozycję, odwołałem się do kategorii liminalności. W jej świetle rola zawodowa czy też zajmowana pozycja zawieszona jest między różnymi zobowiązaniami. Prawnika liminalnego charakteryzuje umiejętność przyjmowania ról, a więc proces wchodzenia i wychodzenia z niej. Aspekt ten podkreśla metadyspozycję do wykonywania wielu ról czy zadań, a która związana jest z brakiem zakorzenienia $\mathrm{w}$ jednej praktyce społecznej. Ujęcie prawnika liminalnego można zatem przeciwstawić wizjom, w których jedna identyfikacja staje się podstawowym punktem odniesienia pozostałych sfer aktywności. Ponadto przedstawiona propozycja podaje w wątpliwość rozróżnienie na wewnętrzny i zewnętrzny punkt widzenia na oznaczenie etykiety, która pozwala kategoryzować ludzi według jednej roli, tej dominującej w życiu społecznym. W zamian podkreśla znaczenie uczestniczenia w różnych praktykach i w konsekwencji uwzględniania w swojej działalności doświadczeń wynikających z udziału w nich. W celu zachowania wymienionych umiejętności instytucjonalną wskazówkę (obecną w kodeksach etyki zawodowej) o stałym podnoszeniu kwalifikacji zawodowych odczytywałbym jako obejmującą swym zakresem również obywatelska wyobraźnię i troskę o człowieczeństwo, zarówno w wymiarze społecznym, jak $\mathrm{i}$ indywidualnym.

Argumentując na rzecz przedłożonej propozycji prawnika liminalnego, odwołałem się do tezy o rozdziale ról, którą można rozpisać na dwa aspekty: zewnętrzny i wewnętrzny. Pierwsze z wymienionych ujęć podkreśla fakt wykonywania wielu ról społecznych, między którymi możliwa jest sytuacja konfliktu. Z kolei drugie ujęcie eksponuje sytuacje możliwego napięcia między zadaniami czy też funkcjami w ramach jednej profesji.

67 Goffman (2008): $47 \mathrm{n}$.

68 O rozróżnieniu na dialogiczny dystans i instrumentalny piszę szerzej w pracy: Kaczmarek (2019): 111-124. 
Zaprezentowana linia argumentacyjna - odwołująca się do tezy o rozdziale ról - jak się wydaje - nie jest jedyna, która wskazuje na przedstawiony charakter roli prawnika. W literaturze, eksponując liminalne ujęcie zawodów usługowych, zwraca się również uwagę na warunki zatrudnienia (pracownicy tymczasowi), organizację pracy i ścieżki kariery (również ze względu na płeć) ${ }^{69}$. W świetle dokonujących się przeobrażeń na rynku pracy, a także zmieniających się warunków społecznych liminalność opisuje stan niepewności, brak stabilności, swoiste zawieszenie, które jest odczuwalne zwłaszcza wśród osób wkraczających dopiero na rynek usług prawniczych ${ }^{70}$. W jakiej mierze wskazane racje, odwołujące się do uwarunkowania społeczno-kulturowego, moga również stanowić argumentację na rzecz myślenia o prawniku w kategoriach liminalności, to pytanie, na które nie chciałbym jeszcze odpowiadać.

Przemystaw Kaczmarek

Uniwersytet Wroctawski

przemyslaw.kaczmarek@uwr.edu.pl

https://orcid.org/0000-0002-3436-4043

Arczewska, M. (2009). Społeczne role sędziów rodzinnych. Warszawa.

Borg, E., Söderlund, J. (2015). Liminality competence: an interpretative study of mobile project workers' conception of liminality at work. Management Learning 46(3): 260-279.

Borucka-Arctowa, M., Skapska, G. (1993). Teoretyczne problemy socjalizacji prawnej, [w:] M. Borucka-Arctowa, Ch. Kourilsky (red.), Socjalizacja prawna. Warszawa: 11-26.

Costas, J., Fleming P. (2009). Beyond dis-identification: a discursive approach to self-alienation in contemporary organizations. Human Relations 62(3): 353-378.

Czapska, J. (1989). Konflikty związane z pełnieniem roli prawnika-uczestnika wymiaru sprawiedliwości, [w:] G. Skapska, J. Czapska, M. Kozłowska, Społeczne role prawników (sędziów, prokuratorów, adwokatów), Wrocław-Warszawa-Kraków-Gdańsk-Łódź: 29-54.

Goffman, E. (2006). Rytuał interakcyjny. Tłum. A. Szulżycka. Warszawa.

Goffman, E. (2008). Człowiek w teatrze życia codziennego. Tłum. H. Datner-Śpiewak, P. Śpiewak, Warszawa.

Goffman, E. (2010). Spotkania. Dwa studia z socjologii interakcji. Tłum. P. Tomanek, Kraków.

Gordon, R.W. (2000). Why lawyers can't just be hired guns, [w:] D.L. Rhode (ed.), Ethics in Practice: Lawyers' Roles, Responsibilities, and Regulation. Oxford-New York: 42-55.

Ibarra, H., Barbulescu, R. (2010). Identity as narrative: prevalence, effectiveness, and consequences of narrative identity work in macro work role transitions. The Academy of Management Review 35(1): 135-154.

Ibarra, H., Obodaru, O. (2016). Betwixt and between identities: liminal experience in contemporary careers. Research in Organizational Behavior 36: 1-65. <https://www.researchgate.net/ publication/310592716_Betwixt_and_between_identities_Liminal_experience_in_contemporary_careers>.

Jabłońska-Bonca, J., Zeidler, K. (2016). Prawnik a sztuka retoryki i negocjacji. Warszawa.

Jabłoński, P., Kaczmarek, P. (2017). Granice władzy prawniczej w perspektywie polskiej tradycji socjologicznej. Kraków.

Jaskulska, S. (2013). „Rytuał przejścia” jako kategoria analityczna. Przyczynek do dyskusji nad badaniem rytualnego oblicza rzeczywistości szkolnej. Studia Edukacyjne 26: 79-97.

Kaczmarek, P. (2019). Dystans do roli w zawodzie prawnika. Warszawa.

${ }^{69}$ Ybema, Beech, Ellis (2011): 27-28.

${ }^{70}$ Kocemba (2018): 246-248; Jabłońska-Bonca, Zeidler (2016): rozdz. I. 
Kaczmarek, P. (2020). Rola prawnika jako argument w obronie etyki kodeksowej. Acta Universitatis Wratislaviensis. Przegląd Prawa i Administracji 120(1): 43-54.

Kamir, R. (2014). Hollywood's hero-lawyer: a liminal character and champion of equal liberty, [w:] A. Wagner, R.K. Sherwin (eds.). Law, Culture and Visual Studies. Dordrecht-HeidelbergNew York-London: 747-773.

Kennedy, D. (2014). The hermeneutic of suspicion in contemporary American legal thought. Law and Critique 25(2): 91-139.

Kocemba, K. (2018). Prekaryzacja młodych prawników w Polsce. Folia Iuridica Universitatis Wratislaviensis 7(1): 243-262.

Lazari-Pawłowska, I. (1971). Etyki zawodowej jako role społeczne, [w:] A. Sarapata (red.) Etyka zawodowa. Warszawa: 33-73.

Łodziński, S., Ząbek, M. (2010). Ludzie w zawieszeniu. Dylematy wykorzenienia i zakorzenienia w zbiorowości uchodźców, [w:] A. Lompart (red.), Jednostka zakorzeniona? Wykorzeniona? Warszawa: 93-119.

Mańko, R. (2018). W stronę krytycznej filozofii orzekania. Polityczność, etyka, legitymizacja. Łódź.

Markovits, D. (2008). A Modern Legal Ethics. Adversary Advocacy in a Democratic Age. PrincetonOxford.

Mayntz, R. (1970). Role distance, role identification, and amoral role behavior. European Journal of Sociology 11(2): 368-378.

McCabe, M., Briody, E.K. (2016). Working in liminal states: fluidity and transformation in organizations. Journal of Business Anthropology 2 (special issue): 1-12.

Mindes, M.W., Acock, A.C. (1982). Trickster, hero, helper: a report on the lawyer image. American Bar Foundation Research Journal 177(1): 177-233.

Newcomb, T., Turner, R.H., Converse, P.E. (1970). Psychologia społeczna. Studium interakcji ludzkich. Tłum. H. Muszyński i inni. Warszawa.

Söderlund, J., Borg, E. (2018). Liminality in management and organization studies: process, position and place. International Journal of Management Reviews 20: 880-902.

Stier, S. (1991). Legal ethics: the integrity thesis. Ohio State Law Journal 52(2): 551-609.

Strauss, A.L. (2013). Zwierciadła i maski. W poszukiwaniu tożsamości. Przeł. A. Hałas. Kraków.

Turner, R.H. (1988). Personality in society: social psychology's contribution to sociology. Social Psychology Quarterly 51(1): 1-10.

Turner, R.H. (1990). Role change. Annual Review of Sociology 16: 87-110.

Turner, R.H. (2006). Role theory, [w:] J.H. Turner (ed.). Handbook of Sociological Theory, Springer: $233-254$.

Turner, V. (2005a). Gry społeczne, pola i metafory. Symboliczne działanie w społeczeństwie. Tłum. W. Usakiewicz. Kraków.

Turner, V. (2005b). Od rytuału do teatru. Powaga zabawy. Tłum. M. i J. Dziekanowie. Warszawa.

Turner, V. (2006). Las symboli. Aspekty Rytuałów u ludu Ndembu. Tłum. A. Szyjewski. Kraków.

Turner, V. (2010). Proces rytualny. Struktura i antystruktura. Tłum. E. Dżurak. Warszawa.

Van Gennep, A. (2006). Obrzędy przejścia. Systematyczne studium ceremonii: o bramie i progu, o gościnności i adopcji. Tłum. B. Biały. Warszawa.

Wendel, W.B. (2014). Ethics and Law: An Introduction. Cambridge.

Ybema, S., Beech, N., Ellis, N. (2011). Transitional and perpetual liminality: an identity practice perspective. Anthropology Southern Africa 34(1\&2): 21-29.

Ybema, S., Keenoy, T., Oswick, C., Beverungen, A., Ellis, N., Sabelis, I. (2009). Articulating identities. Human Relations 62(3): 299-322.

Zienkiewicz, A. (2019). Prawnik jako peacemaker - przeprosiny, przebaczenie, pojednanie w opanowywaniu sporów prawnych. Ruch Prawniczy, Ekonomiczny i Socjologiczny 81(4): $43-57$. 


\section{PERFORMING A PROFESSIONAL ROLE: A LAWYER'S LIMINALITY}

\section{$\mathrm{Su} \mathrm{m} \mathrm{m}$ a r y}

The article has two main goals. The first is to establish the image of a lawyer's liminality. To carry out this task, I adapt the category of liminality to the description of the legal profession. The second is to present argumentation that draws on the thesis about the differentiation of roles, which will assist consideration of the main proposition. These goals are implemented in three stages. My starting point is an exploration of the concept of liminality. In this regard, I refer to the findings of two anthropologists: Arnold van Gennep and Victor Turner. In the next step, I discuss, following Jonas Söderlund and Elisabeth Borg, the dominant ways of examining liminality in the sociology of the organization and management of professional groups. In the last section, I relate these findings to the thesis about the differentiation of roles, distinguishing two of its approaches. As part of this reference, I try to show that the thesis on the differentiation of roles fits into the liminal approach to the professional role. This conclusion is an argument in favour of thinking about a lawyer's liminality.

Keywords: liminality; professional role; identity of a lawyer; role-differentiation thesis 
